DOI: 10.20472/IAC.2018.039.029

DARYA MAOZ

Hadassah Academic College, Israel, Israel

\title{
CROSSING ROMANTIC BORDERS - JEWISH FEMALE TOURISTS AND LOCAL ARAB MEN IN SINAI
}

\begin{abstract}
:
In 1979, Israel and Egypt signed the Camp David Accords, mandating Israel's withdrawal from the Sinai Peninsula, which had been seized from Egypt in the Six Day War of 1967. Since then Egypt and Israel's relations have known ups and downs, but have generally remained cold. Many Egyptians hold harsh feelings toward Israel, especially since the second Intifada (an uprising of the Palestinians in Gaza and the West Bank) which broke out in September 2000. The same mistrust and negative attitude is also shared by many Israelis toward Egypt.

The current study examines the fascinating subject of romantic relations between Israeli-jewish women tourists and local Arab men in The Sinai Peninsula, a part of Egypt. The only place this special encounter could happen - against the attitudes of societies and families - is through tourism, which enables breaking even the strongest walls and let two rival sides live together in the most intimate way.

Romantic relations between Jews and Arabs are rare and face obstacles and considerable opposition. In Israel, such relations elicit "moral panic," and there is a tendency to criminalize the Arab men and to portray the Jewish women as weak and foolish. Academic attention to mixed-faith relationships in Israel is quite rare and has focused on negative aspects.

The current study forms part of a wider research conducted over a period of 14 years (2004-2018) designed to assess the relations and mutual attitudes and perceptions of Israelis and Egyptians using qualitative methods such as fieldwork, participant observation, semi-structured in-depth interviews, and informal conversations with Israeli tourists and Arab hosts.

The purpose of the current study is to examine the romantic relations between Israeli-Jewish women and Arab men in a very complex sociopolitical context. Who are these people, how do they perceive their relations, and what are the political and emotional aspects (and implications) of their choices?
\end{abstract}

\section{Keywords:}

Romance tourism; interfaith relations; Qualitative methods; The Arab-Israeli conflict 